Review

\title{
Familial Hypercholesterolemia: Do HDL Play a Role?
}

\author{
Juan Pedro-Botet ${ }^{1,2,3, *}$, Elisenda Climent ${ }^{1,2,3}$ and David Benaiges ${ }^{1,2,3} \mathbb{D}$ \\ 1 Endocrinology and Nutrition Department, Hospital del Mar, 08003 Barcelona, Spain; \\ 61063@parcdesalutmar.cat (E.C.); 96002@parcdesalutmar.cat (D.B.) \\ 2 Department of Medicine, Universitat Autònoma de Barcelona, Campus Universitari Mar, \\ 08003 Barcelona, Spain \\ 3 Institut Hospital del Mar d'Investigacions Mèdiques (IMIM), 08003 Barcelona, Spain \\ * Correspondence: 86620@parcdesalutmar.cat; Tel.: +34-932483902; Fax: +34-932483254
}

Citation: Pedro-Botet, J.; Climent, E.; Benaiges, D. Familial

Hypercholesterolemia: Do HDL Play

a Role? Biomedicines 2021, 9, 810 .

https://doi.org/10.3390/

biomedicines 9070810

Academic Editors: Joan

Carles Escolà-Gil, Josep Julve and

Stefano Bellosta

Received: 20 May 2021

Accepted: 9 July 2021

Published: 13 July 2021

Publisher's Note: MDPI stays neutral with regard to jurisdictional claims in published maps and institutional affiliations.

Copyright: (C) 2021 by the authors. Licensee MDPI, Basel, Switzerland. This article is an open access article distributed under the terms and conditions of the Creative Commons Attribution (CC BY) license (https:/ / creativecommons.org/licenses/by/ $4.0 /)$.

\begin{abstract}
Cardiovascular disease (CVD) in heterozygous familial hypercholesterolemia (HeFH), the most frequent monogenic disorder of human metabolism, is largely driven by low-density lipoprotein (LDL) cholesterol concentrations. Since the CVD rate differs considerably in this population, beyond the lifetime LDL cholesterol vascular accumulation, other classical risk factors are involved in the high cardiovascular risk of HeFH. Among other lipoprotein disturbances, alterations in the phenotype and functionality of high-density lipoproteins (HDL) have been described in $\mathrm{HeFH}$ patients, contributing to the presence and severity of CVD. In fact, HDL are the first defensive barrier against the burden of high LDL cholesterol levels owing to their contribution to reverse cholesterol transport as well as their antioxidant and anti-inflammatory properties, among others. In this context, the present narrative review aimed to focus on quantitative and qualitative abnormalities in HDL particles in $\mathrm{HeFH}$, encompassing metabolic, genetic and epigenetic aspects.
\end{abstract}

Keywords: familial hypercholesterolemia; cardiovascular disease; high density lipoproteins; HDL functionality; genetics; epigenetics

\section{Introduction}

Heterozygous familial hypercholesterolemia $(\mathrm{HeFH})$, the most frequent human metabolism monogenic disorder caused by mutations in the genes encoding for the low-density lipoprotein (LDL) receptor [1], apolipoprotein (Apo) B-100 [2], proprotein convertase subtilisin/kexin-type 9 (PCSK9) [3] or Apo E [4], entails high LDL cholesterol concentrations, resulting in a high lifetime risk for cardiovascular disease (CVD). In this respect, a subject with a pathogenic FH mutation and LDL cholesterol > $190 \mathrm{mg} / \mathrm{dL}$ has a 22-fold increased risk of premature CVD compared with a mutation-negative subject with LDL cholesterol $<130 \mathrm{mg} / \mathrm{dL}$ [5]. Fortunately, the introduction and widespread use of statins have markedly improved the prognosis of HeFH patients owing to their efficacy in LDL cholesterol reduction [6-9].

Although CVD in HeFH is largely driven by LDL cholesterol concentrations, its prevalence is extremely variable, even in subjects sharing the same pathogenic mutation [10]. Besides specific HeFH risk factors such as the type of mutation or the presence of tendon xanthomas [11], classical risk factors such as age, male sex, smoking, overweight/obesity, hypertension and low high-density lipoprotein (HDL) cholesterol may also account for the CVD rate differences in the HeFH population [9,12-16].

Concerning HDL, these nanoparticles are traditionally characterized by their cholesterol and protein content (Figure 1); however, this cholesterol is not directly involved in the atheroprotective functions of HDL [17,18]. Discovered in 1929 by Macheboeuf [19] at the Pasteur Institute in Paris as lipid-rich $\alpha$-globulins isolated from horse serum, these lipoproteins exhibit heterogeneity in their structure, metabolism and biological functions (Figure 2). It must be taken into account that HDL particles, the first defensive barrier against the 
burden of high LDL cholesterol levels, are subject to constant intravascular remodeling that generates multiple HDL phenotypes. The present narrative review aimed to focus on quantitative and qualitative abnormalities in HDL particles in $\mathrm{HeFH}$, encompassing metabolic, genetic and epigenetic aspects.

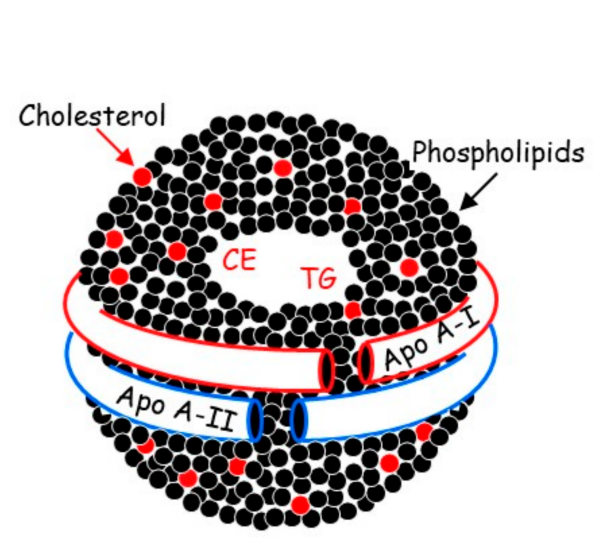

HDL, 7-12 nm $\varnothing$

(hydrated density, 1.063-1.21 $\mathrm{g} / \mathrm{mL}$ )
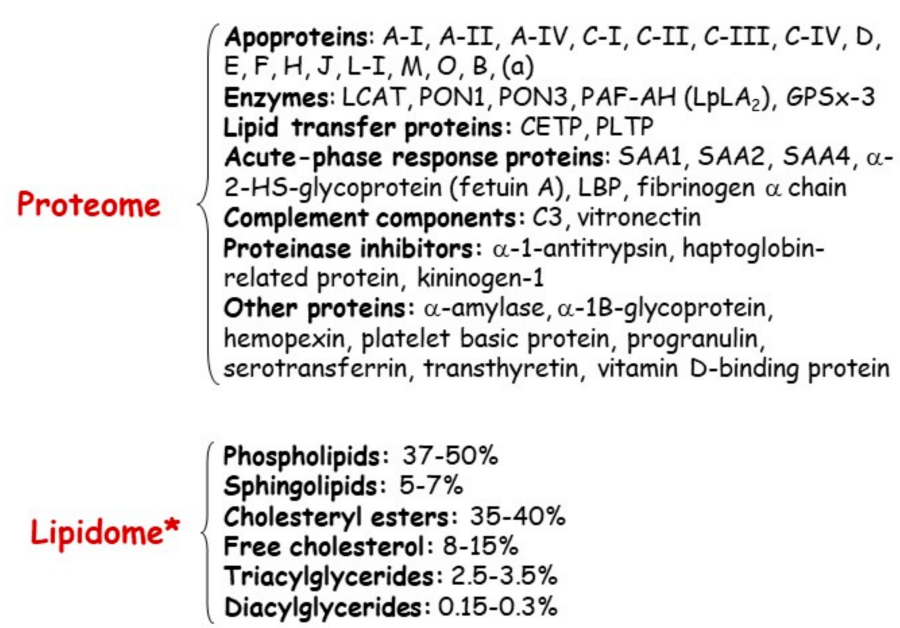

MicroRNA $\left\{\begin{array}{l}m i R-33 a, m i R-30 c, m i R-92 a, m i R-122, m i R-125 a, m i R-126, \\ m i R-145, m i R-146 a, m i R-150, m i R-155, m i R-223, m i R-378, \\ m i R-486, \text { and miR-17/92 }\end{array}\right.$

Figure 1. Main lipid and protein components of high-density lipoproteins. Apo, apolipoprotein; CE, cholesteryl esters; C3, complement 3; CETP, cholesteryl ester transfer protein; GSPx-3, glutathione selenoperoxidase 3; HDL, high-density lipoproteins; LCAT, lecithin:cholesterol acyltransferase; LBP, lipid-binding serum glycoproteins; Lp-PLA2, lipoproteinassociated phospholipase A2; MiRNA, microRNA; PAF-AH, platelet-activating factor acetyl hydrolase; PLPT, phospholipid transfer protein; PON, paraoxonase; SAA, serum amyloid A; TG, triglycerides. ${ }^{*}$ HDL content in mol\% of total lipids.

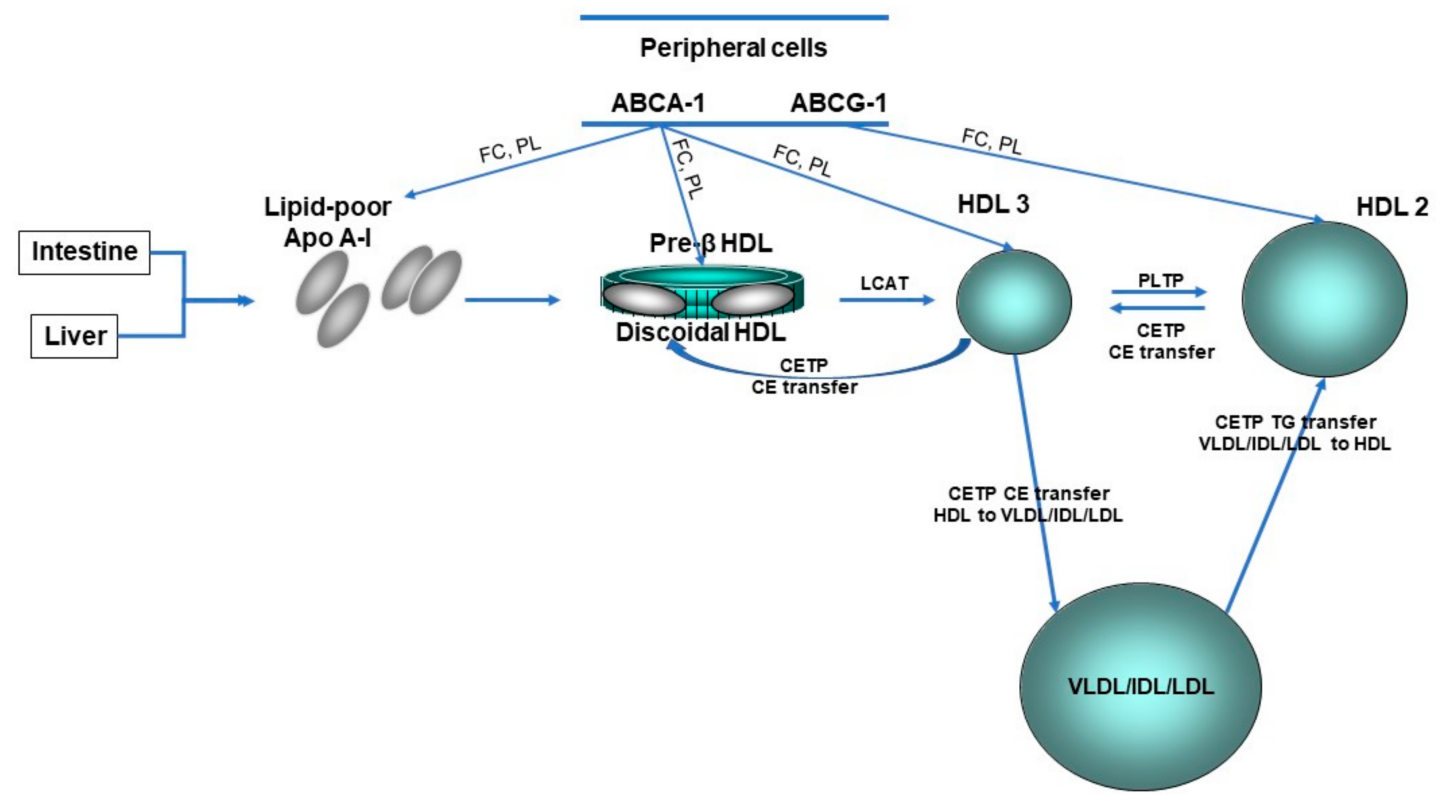

Figure 2. HDL lifecycle. The liver and gut synthesize apolipoprotein (Apo) A-I which become discoid nascent HDL after interaction with the ATP-binding cassette transporter A-1 (ABCA-1). Pre- $\beta$ HDL is converted by lipidation with free cholesterol (FC) and phospholipids (PL) via ABCA-1 and ABCG-1 and cholesterol esterification via lecithin:cholesterol acyltranferase (LCAT) to spherical HDL3. HDL3 is converted to HDL2 by the fusion of small HDL particles activated by phospholipid transfer protein (PLTP). CE, cholesteryl ester; CETP, cholesteryl ester transfer protein; HDL, high-density lipoprotein; IDL, intermediate-density lipoprotein; LDL, low-density lipoprotein; TG, triglyceride; VLDL, very lowdensity lipoprotein. 


\section{Low HDL Cholesterol Phenotype in HeFH}

Since the Framingham Heart Study in 1986 [20], the epidemiological association between low HDL cholesterol levels and an increased risk of coronary heart disease has been well established in several large population cohorts [21,22]. Based on these data, low $\mathrm{HDL}$ cholesterol concentrations are $<1.0 \mathrm{mmol} / \mathrm{L}(40 \mathrm{mg} / \mathrm{dL}$ ) for men and $<1.2 \mathrm{mmol} / \mathrm{L}$ $(48 \mathrm{mg} / \mathrm{dL})$ for women.

One of the first references in the scientific literature stemmed from a letter by Seftel [23] to the Editor of the New England Journal of Medicine pointing out from Goldstein et al. data [24] the low HDL cholesterol levels in FH subjects. With all subsequent clinical studies taken together, ambivalent results regarding HDL cholesterol concentrations have been reported in this specific population. Low HDL cholesterol concentrations have been associated with a $37 \%$ relative increase in cardiovascular risk [12,25] and suggested as a strong marker of preclinical carotid atherosclerosis in $\mathrm{HeFH}$ patients [26]. Furthermore, from a French-Canadian cohort, Khoury et al. [27] discovered HeFH individuals aged $>70$ years without cardiovascular events and tried to establish CVD-free survival factors. Beyond LDL cholesterol, female sex, non-smoking, high HDL cholesterol and hyperadiponectinemia were the main markers of longer CVD risk-free survival in $\mathrm{HeFH}$. By contrast, no differences in HDL cholesterol concentrations were found in other studies when $\mathrm{HeFH}$ were compared with non-FH populations [28-30]. Therefore, environmental and genetic interactions involved in HDL metabolism could explain, at least in part, these discrepancies $[17,18]$.

HDL cholesterol concentrations are influenced by the turnover of Apo A-I, their major protein component. Kinetic studies with stable isotopes have supported increased HDL-Apo A-I catabolism and secretion, thus maintaining its serum concentration balanced in $\mathrm{HeFH}$ patients [31]. The former finding may be related to enhanced cholesteryl ester transfer protein (CETP) activity in HeFH that leads to the triglyceride enrichment of HDL and/or to Apo E-enriched HDL that is catabolized by an Apo E receptor-mediated pathway; this concurs with the smaller HDL particle size found in HeFH patients [32]. Additionally, FH patients have elevated concentrations of small nascent pre $\beta 1-H D L$ particles [33,34], but lower levels of large HDL2 particles compared to normolipidemic subjects [33]. Interestingly, elevations in plasma apo E have been reported in $\mathrm{FH}$ patients [35], and the APOE genotype might influence plasma HDL cholesterol levels in these patients [36]. Another Apo differentially expressed in $\mathrm{HeFH}$ is Apo L1, with a decreased content of this protein in HDL3 particles [37]. A specific analysis of the HDL3 subfraction in that study revealed a coordinated decrease in the content of Apo L1 and lecithin:cholesterol acyltransferase (LCAT), a key enzyme in HDL metabolism, in HeFH patients with a fatal myocardial infarction during follow-up.

\section{Dysfunctional HDL Particles in HeFH}

HDL functions are often impaired in different clinical settings including FH [17,38-40] owing to compositional changes in proteins, enzymes, lipids and microRNA which entail the loss of their atheroprotective properties (Figure 3).

\subsection{Defective Reverse Cholesterol Transport (RCT)}

Since peripheral tissue is unable to excrete excess free cholesterol, which is toxic for cells, it must be removed by RCT to the liver for utilization and excretion with bile, a role of HDL. Most of the cholesterol is effluxed from cholesterol-laden macrophages to nascent or mature HDL particles and finally transported to the liver in both esterified and unesterified forms. In primary cardiovascular prevention in the general population, cholesterol efflux capacity and the total HDL particle number are each inversely associated with cardiovascular events, regardless of the HDL cholesterol concentration and of each other [22,41]. Hypercholesterolemia induces lipidomic and proteomic variations in HDL particles, thereby damaging their ability to promote macrophage cholesterol efflux. 
This finding stemmed from a study on ischemia-reperfusion injury in pigs, in which the beneficial vascular effects of HDL were abolished by hypercholesterolemia [42].

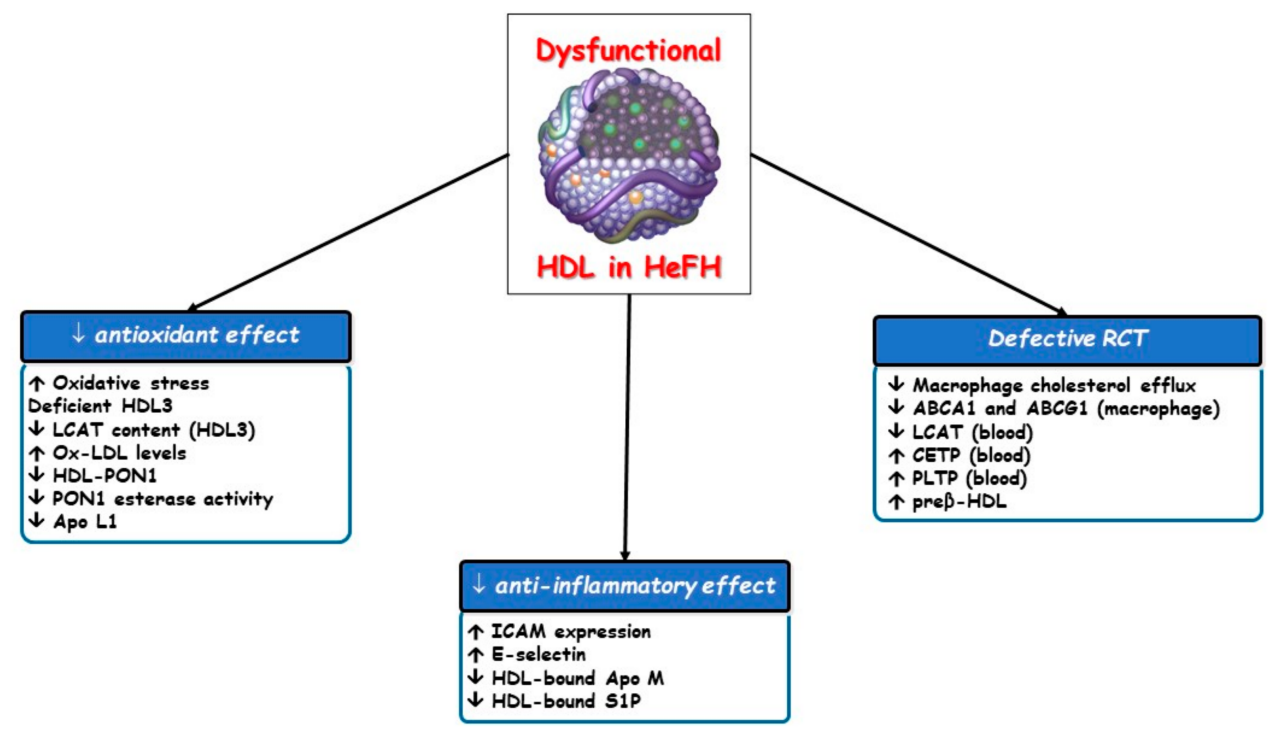

Figure 3. Impaired effects of dysfunctional HDL particles in HeFH. ABCA1, ATP-binding cassette transporter A1; ABCG1, ATP-binding cassette transporter G1; Apo, apolipoprotein; CETP, cholesteryl ester transfer protein; HDL, high-density lipoprotein; ICAM, intracellular adhesion molecule; LCAT, lecithin: cholesterol acyltransferase; Lp-PLA2, lipoprotein-associated phospholipase A2; PLTP, phospholipid transfer protein; PON1, paraoxonase type 1; RCT, reverse cholesterol transport; S1P, sphingosine-1-phosphate.

Notable evidence points to an altered macrophage-specific RCT in HeHF [43] (Figure 4). An impaired RCT, specifically related to the HDL2 subclass, with an inverse relationship between HDL efflux capacity and the development of atherosclerosis has been described in homozygous and $\mathrm{HeFH}$ patients [30]. Nevertheless, those patients were on high-intensity hypocholesterolemic therapy including LDL apheresis and RCT was assessed ex vivo. The decreased efflux of cellular cholesterol to HDL was confirmed when HDL particles were isolated in a study conducted in $71 \mathrm{HeFH}$ patients and 66 normolipidemic subjects, leading to a reduced esterification by LCAT which was associated with an increased CVD risk [44]. Thus, the centripetal transport of cholesterol from the peripheral cells to feces appears altered in $\mathrm{HeFH}$.

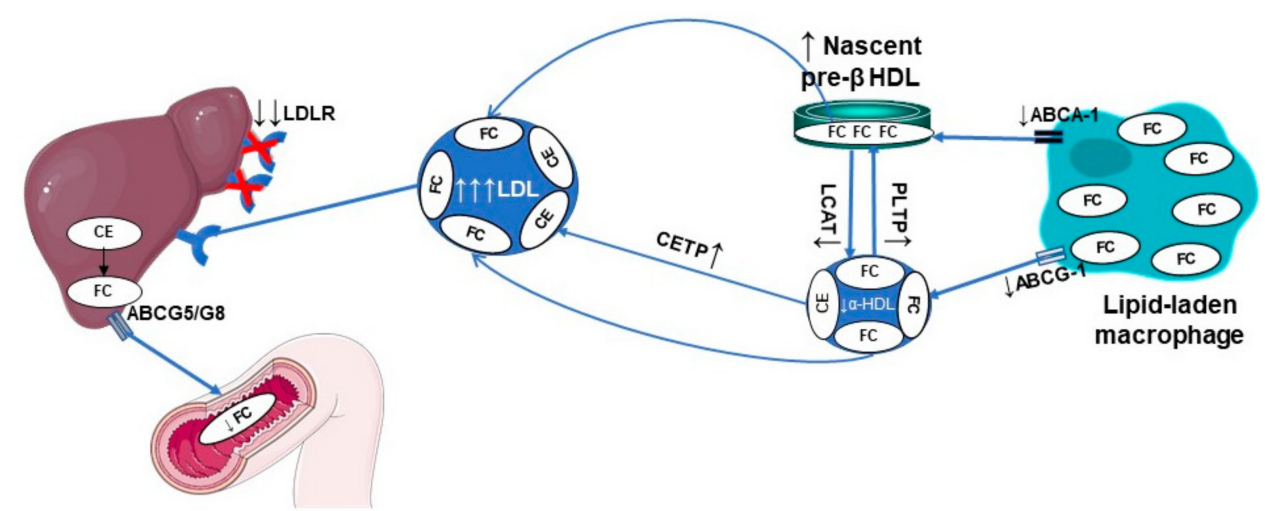

Figure 4. Defective macrophage reverse cholesterol transport in $\mathrm{HeFH}$. ABCA1, ATP-binding cassette transporter A1; ABCG1, ATP-binding cassette transporter G1; ABCG5/G8, ATP-binding cassette transporter G5/G8; Apo, apolipoprotein; CE, cholesteryl ester; CETP, cholesteryl ester transfer protein; FC, free cholesterol; HDL, high-density lipoprotein; LCAT, lecithin: cholesterol acyltransferase; LDL, low-density lipoprotein; LDLR, low-density lipoprotein. 
Versmissen et al. [45] showed that plasma from HeFH patients without CVD had a higher cholesterol efflux capacity than plasma from those with CVD, in comparison to their respective non-FH counterparts. This higher efflux capacity may involve differences in HDL composition including cholesterol, sphingosine-1-phosphate (S1P) and Apo M concentrations. In fact, increased S1P levels in HDL might also point to differences in HDL functionality other than cholesterol efflux capacity. Thus, the cardiovascular risk in HeFH patients appears to be modulated by factors not related to the LDL receptor locus that modifies the HDL composition and the effectiveness of RCT.

More recently, Cedó et al. [46] contributed to the clarification of the role of LDL in macrophage cholesterol efflux. Firstly, they reported that the LDL receptor regulates the reverse transport of macrophage-derived unesterified cholesterol via the concerted action of the HDL-LDL axis in hypercholesterolemic mice. They then assessed the HDLassociated remodeling of lipid transfer proteins and enzymes and their potential to alter HDL composition and macrophage cholesterol efflux in non-treated HeFH patients with an identified LDLR mutation and in normolipidemic subjects of a similar age and sex [34]. Among the most outstanding results, a high LDL particle concentration was linked to dysfunctional HDL particles characterized by their altered remodeling and an impaired capacity to promote cholesterol removal from macrophages. The higher CETP-facilitated lipid transfer, along with the reduced LCAT activity in adolescents with HeFH, indicates that these functional abnormalities may be primarily responsible for the altered HDL remodeling and functionality in younger patients with $\mathrm{HeFH}$.

Regarding other changes in HDL composition, a depletion in phospholipids and an increased relative content of sphingomyelin can impair the capacity to sustain cellular cholesterol efflux in HeFH subjects $[33,38]$. On the other hand, in severe HeFH, LDL apheresis was highly efficient in lowering not only LDL cholesterol concentrations but also large ApoE-containing HDL, pre- $\beta$ HDL, plasma CETP activity and cellular cholesterol efflux measured ex vivo [47], thus reflecting a transient defective RCT.

\subsection{Other Altered HDL Atheroprotective Effects}

Several lines of evidence have suggested enhanced chronic low-grade inflammation and systemic oxidative stress as well as impaired antioxidant and anti-inflammatory effects of HDL in HeFH $[39,48]$. Specifically, a diminished ability to inhibit intracellular adhesion molecule (ICAM)-1 expression in human umbilical vein endothelial cells after tumor necrosis factor-alpha (TNF- $\alpha$ ) induction was demonstrated in HDL3 of HeFH patients with a body mass index $>25 \mathrm{~kg} / \mathrm{m}^{2}$ and premature CVD [49]. In addition, raised soluble ICAM-1 concentrations in HeFH patients compared with non-FH controls were also reported. Moreover, HDL particles of FH patients were shown to be less potent in reducing the repletion of pro-inflammatory oxidized lipids in LDL compared with particles isolated from normolipidemic subjects [50]. Thus, a modified HDL3 anti-inflammatory function would less effectively neutralize the inflammatory scenario caused by the high LDL cholesterol levels in HeFH patients.

Although HDL particles are minor contributors to the overall antioxidant capacity of plasma [51], we must not forget that HDL3 particles are those with the most potent ability to protect LDL from oxidative damage [18], and this antioxidant property has been mainly attributed to LCAT [52]. Thus, a decreased LCAT content in HDL3 particles could reduce their antioxidant potential and favor LDL oxidation and atherosclerosis progression, thereby significantly increasing cardiovascular risk in $\mathrm{FH}$ patients. In fact, $\mathrm{HeFH}$ patients with corneal arcus, an independent predictor of CVD [53], have a lower content of Apo L1, LCAT and paraoxonase type 1 (PON1) in HDL particles [39].

PON1 is an HDL-related enzyme capable of hydrolyzing different substrates which include oxidative pro-oxidant species [54]. In HeFH patients, no association was found between peripheral concentrations of PON1 and carotid intima-media thickness, levels of oxidized LDL and the high sensitivity C-reactive protein [55]. More recently, PON1 esterase 
activity was found to be reduced in HeFH patients compared to healthy relatives [56]. These results should be considered preliminary and thus interpreted with caution.

On the other hand, the type and content of phospholipids are important regulators of HDL functions, producing an interesting relationship between the phosphatidylcholine/sphingomyelin ratio and the antioxidant activity of the HDL3 fraction. Decreased surface total phosphatidylcholine content with raised sphingomyelin and saturated fatty acid contents have been reported in HDL particles isolated from FH patients; this may reflect an increased surface rigidity and an ensuing impaired antioxidant capacity of HDL in $\mathrm{FH}$ [50].

\subsection{MicroRNA Transport}

MicroRNA are important regulators of a large variety of biological processes including lipoprotein metabolism [57]. Desgagné et al. [58] characterized the whole HDL microtranscriptome by next generation sequencing technology in healthy subjects and showed that HDL carry a microRNA profile distinct from that of other carriers in plasma which is not sex-dependent. The transport of endogenous microRNA by HDL was first proposed by Vickers et al. [59] who isolated and distinguished the HDL-microRNA profile in healthy volunteers and HeFH patients, noting significant differences. In this respect, hsa-miR-223, hsa-miR-105 and hsa-miR-106a were observed in the HDL of HeFH patients. In an explorative study, D'Agostino et al. [60] evaluated the association between miR-33a/b and miR-200c and their positive correlation in the plasma of HeFH children and found that they were upregulated. Since then, increasing attention has been paid to achieving a better understanding of the link between HDL-microRNA and HeFH, and HDL-miR-486 and HDL-miR-92a levels found to be more expressed in the LDLR-null group than the LDLR-defective group [61].

\section{Genetics and Epigenetics}

In a recent Mendelian randomization study, Prats-Uribe et al. [62] demonstrated that some qualitative HDL traits related to their size, particle distribution and cholesterol and triglyceride content were associated with cardiovascular risk, while HDL cholesterol concentrations were not. This relationship could be mediated by several HDL-related proteins which could be proposed as potential therapeutic targets in cardiovascular prevention.

As it could not be otherwise, most genetic background studies in $\mathrm{HeFH}$ aimed to determine the genetic polymorphisms responsible for high LDL cholesterol levels. Although low HDL cholesterol concentrations have been shown to affect the severity of the clinical phenotype, little is known about the genetic determinants that may explain a large part of HDL cholesterol variation in the HeFH population. In the largest exploratory Dutch study, van Aalst-Cohen et al. [63] selected 25 DNA polymorphisms in nine genes involved in HDL cholesterol. As expected, the effect of individual genetic polymorphisms on HDL cholesterol concentration was not exciting. In particular, the CETPTaqIB polymorphism demonstrated the strongest association with HDL cholesterol levels but accounted only for $1.1 \%$ of this variation. However, in combination with sex and environmental factors, the combined effects of polymorphisms involved in HDL metabolism could have explained up to $32.5 \%$ of the variation in HDL cholesterol levels.

Epigenetics refers to the heritable and reversible regulation of gene transcription by molecular mechanisms regardless of the DNA sequence. Previous epigenetic studies indicated that DNA methylation, the most understood and stable epigenetic mark, could explain the missing heritability of most complex traits, including plasma lipid levels [64]. In this context, epigenetic changes may account for lipoprotein profile variability, CVD and FH phenotype variability [32,65,66]. Langmann et al. [67] found that epigenetic modifications within the ATP-binding cassette transporter A1 (ABCA1) gene promoter contributed to the interindividual variability in plasma HDL cholesterol levels in FH patients. Next, Guay et al. reported that DNA methylation levels at the ABCA1, CETP and lipoprotein lipase (LPL) gene promoter loci were particularly associated with variations in 
HDL size and cholesterol content, as well as a history of CVD in HeFH $[68,69]$. Later, they described genome-wide epigenetic perturbations which are associated with interindividual HDL cholesterol level variability in HeFH [70]. More specifically, they asserted that DNA methylation variability at multiple loci may explain a significant percentage of the missing HDL cholesterol heritability. They also identified the TNNT1 gene as a new candidate gene for HDL particle phenotype variability. They then demonstrated that both TNNT1 DNA methylation levels and the TNNT1 c.-20G >A polymorphism were associated with HDL cholesterol concentrations in FH and non-FH subjects, and with the prevalence of CVD in FH and non-FH men [71]. These results suggest that both epigenetic and genetic modifications at the 19q13.42 locus are associated with low HDL cholesterol levels and cardiovascular risk. Furthermore, they observed that a higher phospholipid transfer protein (PLTP) DNA methylation was associated with smaller HDL particles and lower concentrations of HDL-phospholipid and HDL cholesterol in men with HeFH. Additionally, they detected that higher hepatic lipase (LIPC) DNA methylation was associated with a lower HDL particle size, HDL-phospholipid, HDL cholesterol and fasting triglyceride concentrations in men [72].

\section{Impact of Current FH Lipid-Lowering Drugs on HDL Functionality}

Although cardiovascular risk reduction in FH patients is clearly linked to the decline in LDL cholesterol levels by statins, these drugs have been shown to improve or restore the functionality of some components of dysfunctional HDL [73-75]. In this respect, statin therapy increases PON1 activity and concentrations in HeFH patients [75].

PCSK9 inhibitors have represented a substantial change in the clinical management of hypercholesterolemia, mainly in the FH population [76,77], due to their high lipid-lowering efficacy and their preventive effects in CVD [78,79]. PCSK9 is involved in cholesterol homeostasis through the LDL receptor degradation pathway. Circulating PCSK9 has been shown to bind to LDL, lipoprotein(a) and HDL [80]. PCSK9 gain-of-function mutations are associated with increased HDL cholesterol and Apo A-I levels [81]. Furthermore, epidemiological studies such as the Dallas Heart Study [82] and the Quebec Child and Adolescent Health and Social Survey [83] also reported a positive relationship between PCSK9 and HDL cholesterol levels. The effect of PCSK9 on the LDL receptor and others including the ApoE receptor two and the very-low-density lipoprotein receptor appears to be responsible for this relationship, possibly by reducing the uptake of the ApoE-containing HDL [84].

However, PCSK9 inhibition by monoclonal antibodies, alirocumab and evolocumab, is associated with a significant increase in HDL cholesterol and apo A-I concentrations [85,86]. This beneficial effect could be explained at least in part by the LDL reduction as the cholesterol acceptor from HDL, an effect that overcomes the improvement of the LDL receptor-mediated ApoE-containing HDL [84]. Thus, the role of PCSK9 on HDL composition and subclasses as well as the impact on RCT should be investigated.

\section{Conclusions}

Although the hallmark of HeFH is the hypocatabolism of LDL particles, growing evidence has highlighted the existence of additional metabolic disturbances in other plasma lipoproteins. In this respect, HDL particles in HeFH patients display qualitative abnormalities, including compositional changes, a reduced capacity to promote cholesterol efflux from macrophages and impaired anti-inflammatory and antioxidant activities, thereby suggesting a potential role of dysfunctional HDL in the high cardiovascular risk of HeFH patients. Thus, although LDL cholesterol concentration is crucial for FH clinical management, further measuring of HDL cholesterol will, at best, only partially reflect the potential role of HDL in CVD risk assessment. This has led to interest in developing new HDL metrics such as particle number, average size, subclasses, and functional assays that might better indicate the atheroprotective functions of HDL [87]. Given the important contri- 
butions of epigenetic studies, further research is required to unravel the key molecular processes involved in the epigenetic control of HDL in both FH and non-FH populations.

Author Contributions: The first version of the manuscript was written by J.P.-B., and revised and approved by D.B. and E.C. All authors have read and agreed to the published version of the manuscript.

Funding: This research received no external funding.

Acknowledgments: The authors thank Christine O'Hara for review of the English version of the manuscript.

Conflicts of Interest: The authors declare no conflict of interest.

\section{References}

1. Bleich, H.L.; Boro, E.S.; Brown, M.S.; Goldstein, J.L. Familial hypercholesterolemia: A genetic defect in the low-density lipoprotein receptor. N. Engl. J. Med. 1976, 294, 1386-1390. [CrossRef]

2. Innerarity, T.L.; Mahley, R.W.; Weisgraber, K.H.; Bersot, T.P.; Krauss, R.M.; Vega, G.L.; Grundy, S.M.; Friedl, W.; Davignon, J.; McCarthy, B.J. Familial defective apolipoprotein B-100: A mutation of apolipoprotein B that causes hypercholesterolemia. J. Lipid Res. 1990, 31, 1337-1349. [CrossRef]

3. Abifadel, M.; Rabès, J.P.; Devillers, M.; Munnich, A.; Erlich, D.; Junien, C.; Varret, M.; Boileau, C. Mutations and polymorphisms in the proprotein convertase subtilisin kexin 9 (PCSK9) gene in cholesterol metabolism and disease. Hum. Mutat. 2009, 30, 520-529. [CrossRef]

4. Cenarro, A.; Etxebarria, A.; de Castro-Orós, I.; Stef, M.; Bea, A.M.; Palacios, L.; Mateo-Gallego, R.; Benito-Vicente, A.; Ostolaza, H.; Tejedor, T.; et al. The p.Leu167del Mutation in APOE gene causes autosomal dominant hypercholesterolemia by down-regulation of LDL receptor expression in hepatocytes. J. Clin. Endocrinol. Metab. 2016, 101, 2113-2121. [CrossRef]

5. Khera, A.V.; Won, H.H.; Peloso, G.M.; Lawson, K.S.; Bartz, T.M.; Deng, X.; van Leeuwen, E.M.; Natarajan, P.; Emdin, C.A.; Bick, A.G.; et al. Diagnostic yield and clinical utility of sequencing familial hypercholesterolemia genes in patients with severe hypercholesterolemia. J. Am. Coll. Cardiol. 2016, 67, 2578-2589. [CrossRef] [PubMed]

6. Besseling, J.; Hovingh, G.K.; Huijgen, R.; Kastelein, J.J.P.; Hutten, B.A. Statins in familial hypercholesterolemia: Consequences for coronary artery disease and all-cause mortality. J. Am. Coll. Cardiol. 2016, 68, 252-260. [CrossRef] [PubMed]

7. Humphries, S.E.; Cooper, J.A.; Seed, M.; Capps, N.; Durrington, P.N.; Jones, B.; McDowell, I.F.W.; Soran, H.; Neil, H.A.W.; Simon Broome Familial Hyperlipidaemia Register Group. Coronary heart disease mortality in treated familial hypercholesterolaemia: Update of the UK Simon Broome FH register. Atherosclerosis 2018, 274, 41-46. [CrossRef]

8. Luirink, I.K.; Wiegman, A.; Kusters, D.M.; Hof, M.H.; Groothoff, J.W.; de Groot, E.; Kastelein, J.J.; Hutten, B.A. 20-Year follow-up of statins in children with familial hypercholesterolemia. N. Engl. J. Med. 2019, 381, 1547-1556. [CrossRef]

9. Perez-Calahorra, S.; Laclaustra, M.; Marco-Benedí, V.; Lamiquiz-Moneo, I.; Pedro-Botet, J.; Plana, N.; Sanchez-Hernandez, R.M.; Amor, A.J.; Almagro, F.; Fuentes, F.; et al. Effect of lipid-lowering treatment in cardiovascular disease prevalence in familial hypercholesterolemia. Atherosclerosis 2019, 284, 245-252. [CrossRef] [PubMed]

10. Ferrieres, J.; Lambert, J.; Lussier-Cacan, S.; Davignon, J. Coronary artery disease in heterozygous familial hypercholesterolemia patients with the same LDL receptor gene mutation. Circulation 1995, 92, 290-295. [CrossRef]

11. Civeira, F.; Castillo, S.; Alonso, R.; Meriño-Ibarra, E.; Cenarro, A.; Artied, M.; Martín-Fuentes, P.; Ros, E.; Pocoví, M.; Mata, P. Tendon xanthomas in familial hypercholesterolemia are associated with cardiovascular risk independently of the low density lipoprotein receptor gene mutation. Arterioscler. Thromb. Vasc. Biol. 2005, 25, 1960-1965. [CrossRef] [PubMed]

12. Jansen, A.C.M.; van Aalst-Cohen, E.S.; Tanck, M.W.; Trip, M.D.; Lansberg, P.J.; Liem, A.H.; van Lennep, H.W.; Sijbrands, E.J.; Kastelein, J.J. The contribution of classical risk factors to cardiovascular disease in familial hypercholesterolaemia: Data in 2400 patients. J. Intern. Med. 2004, 25, 482-490. [CrossRef]

13. Santos, R.D.; Gidding, S.S.; Hegele, R.A.; Cuchel, M.A.; Barter, P.J.; Watts, G.F.; Baum, S.J.; Catapano, A.L.; Chapman, M.J.; Defesche, J.C.; et al. Defining severe familial hypercholesterolaemia and the implications for clinical management: A consensus statement from the International Atherosclerosis Society Severe Familial Hypercholesterolemia Panel. Lancet Diabetes Endocrinol. 2016, 4, 850-861. [CrossRef]

14. De Isla, L.P.; Alonso, R.; Mata, N.; Fernández-Pérez, C.; Muñiz, O.; Díaz-Díaz, J.L.; Saltijeral, A.; Fuentes-Jiménez, F.; de Andrés, R.; Zambón, D.; et al. Predicting cardiovascular events in familial hypercholesterolemia: The SAFEHEART registry (Spanish Familial Hypercholesterolemia Cohort Study). Circulation 2017, 135, 2133-2144. [CrossRef] [PubMed]

15. Paquette, M.; Baass, A. Predicting cardiovascular disease in familial hypercholesterolemia. Curr. Opin. Lipidol. 2018, 29, 299-306. [CrossRef] [PubMed]

16. Akioyamen, L.E.; Genest, J.; Chu, A.; Inibhunu, H.; Ko, D.T.; Tu, J.V. Risk factors for cardiovascular disease in heterozygous familial hypercholesterolemia: A systematic review and meta-analysis. J. Clin. Lipidol. 2019, 13, 15-30. [CrossRef]

17. Barter, P.J.; Rye, K.A. HDL cholesterol concentration or HDL function: Which matters? Eur. Heart J. 2017, 38, 2487-2489. [CrossRef] 
18. Rosenson, R.S.; Bryan Brewer, H., Jr.; Barter, P.J.; Björkegren, J.L.M.; Chapman, M.J.; Gaudet, D.; Kim, D.S.; Niesor, E.; Rye, K.A.; Sacks, F.M.; et al. HDL and atherosclerotic cardiovascular disease: Genetic insights into complex biology. Nat. Rev. Cardiol. 2018, 15, 9-19. [CrossRef]

19. Macheboeuf, M. Recherches sur les phosphoaminolipides du sérum sanguin. Nature des phospholipides liés aux albumines du sérum de cheval à l'état de cenapses acido-précipitables. Bull. Soc. Chim. Biol. (Paris) 1929, 11, 485-503.

20. Castelli, W.P.; Garrison, R.J.; Wilson, P.W.; Abbott, R.D.; Kalousdian, S.; Kannel, W.B. Incidence of coronary heart disease and lipo-protein cholesterol levels. The Framingham Study. JAMA 1986, 256, 2835-2838. [CrossRef]

21. Emerging Risk Factors Collaboration; Di Angelantonio, E.; Sarwar, N.; Perry, P.; Kaptog, S.; Ray, K.K.; Thompson, A.; Wood, A.M.; Lewington, S.; Sattar, N.; et al. Major lipids, apolipoproteins, and risk of vascular disease. JAMA 2009, 302, $1993-2000$.

22. Mackey, R.H.; Greenland, P.; Goff, D.C.; Lloyd-Jones, D.; Sibley, C.T.; Mora, S. High-density lipoprotein cholesterol and particle concentrations, carotid atherosclerosis, and coronary events: MESA (Multi-Ethnic Study of Atherosclerosis). J. Am. Coll. Cardiol. 2012, 60, 508-516. [CrossRef] [PubMed]

23. Seftel, H.C. HDL cholesterol in familial hypercholesterolemia. N. Engl. J. Med. 1984, 310, 125.

24. Goldstein, J.L.; Kita, T.; Brown, M.S. Defective lipoprotein receptors and atherosclerosis. Lessons from an animal counterpart of familial hypercholesterolemia. N. Engl. J. Med. 1983, 309, 288-296. [PubMed]

25. Real, J.T.; Chaves, F.J.; Martínez-Usó, I.; García-García, A.B.; Ascaso, J.F.; Carmena, R. Importance of HDL cholesterol levels and the total/HDL cholesterol ratio as a risk factor for coronary heart disease in molecularly defined heterozygous familial hypercho-lesterolaemia. Eur. Heart J. 2001, 22, 465-471. [CrossRef]

26. Junyent, M.; Cofán, M.; Núñez, I.; Gilabert, R.; Zambón, D.; Ros, E. Influence of HDL cholesterol on preclinical carotid atherosclerosis in familial hypercholesterolemia. Arter. Thromb. Vasc. Biol. 2006, 26, 1107-1113. [CrossRef] [PubMed]

27. Khoury, E.; Brisson, D.; Roy, N.; Tremblay, G.; Gaudet, D. Identifying Markers of Cardiovascular Event-Free Survival in Familial Hypercholesterolemia. J. Clin. Med. 2020, 10, 64. [CrossRef] [PubMed]

28. Galvan, A.Q.; Santoro, D.; Natali, A.; Sampietro, T.; Boni, C.; Masoni, A.; Buzzigoli, G.; Ferrannini, E. Insulin sensitivity in familial hypercholesterolemia. Metabolism 1993, 42, 1359-1364. [CrossRef]

29. Gaudet, D.; Vohl, M.C.; Perron, P.; Tremblay, G.; Gagné, C.; Lesiège, D.; Bergeron, J.; Moorjani, S.; Despréset, J.-P. Relationships of abdominal obesity and hyperinsulinemia to angiographically assessed coronary artery disease in men with known mutations in the LDL receptor gene. Circulation 1998, 97, 871-877. [CrossRef]

30. Chemello, K.; García-Nafría, J.; Gallo, A.; Martín, C.; Lambert, G.; Blom, D. Lipoprotein metabolism in familial hypercholesterolemia. J. Lipid Res. 2021, 62, 100062. [CrossRef]

31. Frénais, R.; Ouguerram, K.; Maugeais, C.; Marchini, J.S.; Benlian, P.; Bard, J.; Magot, T.; Krempf, M. Apolipoprotein A-I kinetics in heterozygous familial hypercholesterolemia: A stable isotope study. J. Lipid Res. 1999, 40, 1506-1511. [CrossRef]

32. Hogue, J.C.; Lamarche, B.; Gaudet, D.; Tremblay, A.J.; Després, J.P.; Bergeron, J.; Gagnéa, C.; Couturea, P. Association of heterozygous familial hypercholesterolemia with smaller HDL particle size. Atherosclerosis 2007, 190, 429-435. [CrossRef] [PubMed]

33. Bellanger, N.; Orsoni, A.; Julia, Z.; Fournier, N.; Frisdal, E.; Duchene, E.; Bruckert, E.; Carrie, A.; Bonnefont-Rousselot, D.; Pirault, J.; et al. Atheroprotective reverse cholesterol transport pathway is defective in familial hypercholesterolemia. Arter. Thromb. Vasc. Biol. 2011, 31, 1675-1681. [CrossRef] [PubMed]

34. Cedó, L.; Plana, N.; Metso, J.; Lee-Rueckert, M.; Sanchez-Quesada, J.L.; Kovanen, P.T.; Jauhiainen, M.; Masana, L.; Escolà-Gil, J.C.; Blanco-Vaca, F. Altered HDL remodeling and functionality in familial hypercholesterolemia. J. Am. Coll. Cardiol. 2018, 71, 466-468. [CrossRef] [PubMed]

35. Gibson, J.C.; Goldberg, R.B.; Rubinstein, A.; Ginsberg, H.N.; Brown, W.V.; Baker, S.; Joffe, B.I.; Seftel, H.C. Plasma lipoprotein distribution of apolipoprotein E in familial hypercholesterolemia. Arteriosclerosi. 1987, 7, 401-407. [CrossRef] [PubMed]

36. Miltiadous, G.; Cariolou, M.A.; Elisaf, M. HDL cholesterol levels in patients with molecularly defined familial hypercholesterolemia. Ann. Clin. Lab. Sci. 2002, 32, 50-54.

37. Cubedo, J.; Padro, T.; Alonso, R.; Mata, P.; Badimon, L. ApoL1 levels in high density lipoprotein and cardiovascular event presentation in patients with familial hypercholesterolemia. J. Lipid Res. 2016, 57, 1059-1073. [CrossRef]

38. Rosenson, R.S.; Bryan Brewer, H., Jr.; Ansell, B.J.; Barter, P.; Chapman, M.J.; Heinecke, J.W.; Kontush, A.; Tall, A.R.; Webb, N.R. Dysfunctional HDL and atherosclerotic cardiovascular disease. Nat. Rev. Cardiol. 2016, 13, 48-60. [CrossRef]

39. Ganjali, S.; Momtazi, A.A.; Banach, M.; Kovanen, P.T.; Stein, E.A.; Sahebkar, A. HDL abnormalities in familial hypercholesterolemia: Focus on biological functions. Prog. Lipid Res. 2017, 67, 16-26. [CrossRef]

40. Wong, N.K.P.; Nicholls, S.J.; Tan, J.T.M.; Bursill, C.A. The role of high-density lipoproteins in diabetes and its vascular complications. Int. J. Mol. Sci. 2018, 19, 1680. [CrossRef] [PubMed]

41. Rohatgi, A.; Khera, A.; Berry, J.D.; Givens, E.G.; Ayers, C.R.; Wedin, K.E.; Neeland, I.J.; Yuhanna, I.S.; Rader, D.R.; de Lemos, J.A.; et al. HDL cholesterol efflux capacity and incident cardiovascular events. N. Engl. J. Med. 2014, 371, 2383-2393. [CrossRef]

42. Padró, T.; Cubedo, J.; Camino, S.; Bejar, M.T.; Ben-Aicha, S.; Mendieta, G.; Escolà-Gil, J.C.; Escate, R.; Gutiérrez, M.; Casaní, L.; et al. Detrimental effect of hypercholesterolemia on high-density lipoprotein particle remodeling in pigs. J. Am. Coll. Cardiol. 2017, 70, 165-178. [CrossRef]

43. Escolà-Gil, J.C.; Rotllan, N.; Julve, J.; Blanco-Vaca, F. Reverse cholesterol transport dysfunction is a feature of familial hypercholesterolemia. Curr. Atheroscler. Rep. 2021, 23, 29. [CrossRef] 
44. Martinez, L.R.; Santos, R.D.; Miname, M.H.; Deus, D.F.; Lima, E.S.; Maranhão, R.C. Transfer of lipids to high-density lipoprotein (HDL) is altered in patients with familial hypercholesterolemia. Metabolism 2013, 62, 1061-1064. [CrossRef]

45. Versmissen, J.; Vongpromek, R.; Yahya, R.; van der Net, J.B.; van Vark-van der Zee, L.; Blommesteijn-Touw, J.; Wattimena, D.; Rietveld, T.; Pullinger, C.R.; Christoffersen, C.; et al. Familial hypercholesterolaemia: Cholesterol efflux and coronary disease. Eur. J. Clin. Investig. 2016, 46, 643-650. [CrossRef]

46. Cedo, L.; Metso, J.; Santos, D.; García-León, A.; Plana, N.; Sabate-Soler, S.; Rotllan, N.; Rivas-Urbina, A.; Mendez-Lara, K.A.; Tondo, M.; et al. LDL receptor regulates the reverse transport of macrophage-derived unesterified cholesterol via concerted action of the HDL-LDL axis: Insight from mouse models. Circ. Res. 2020, 127, 778-792. [CrossRef] [PubMed]

47. Orsoni, A.; Villard, E.F.; Bruckert, E.; Robillard, P.; Carrie, A.; Bonnefont-Rousselot, D.; Chapman, M.J.; Dallinga-Thie, G.M.; Le Goff, W.; Guerin, M. Impact of LDL apheresis on atheroprotective reverse cholesterol transport pathway in familial hypercholesterolemia. J. Lipid Res. 2012, 53, 767-775. [CrossRef]

48. Bahrami, A.; Liberale, L.; Reiner, Ž.; Carbone, F.; Montecucco, F.; Sahebkar, A. Inflammatory biomarkers for cardiovascular risk stratification in familial hypercholesterolemia. Rev. Physiol. Biochem. Pharmacol. 2020, 177, 25-52. [CrossRef] [PubMed]

49. Balstad, T.R.; Holven, K.B.; Ottestad, I.O.; Otterdal, K.; Halvorsen, B.; Myhre, A.M.; Ose, L.; Nenseter, M. Altered composition of HDL3 in FH subjects causing a HDL subfraction with less atheroprotective function. Clin. Chim. Acta 2005, 359, 171-178. [CrossRef] [PubMed]

50. Hussein, H.; Saheb, S.; Couturier, M.; Atassi, M.; Orsoni, A.; Carrié, A.; Therond, P.; Chantepie, S.; Robillard, P.; Bruckert, E.; et al. Small, dense high-density lipoprotein 3 particles exhibit defective antioxidative and anti-inflammatory function in familial hypercholesterolemia: Partial correction by low-density lipoprotein apheresis. J. Clin. Lipidol. 2016, 10, 124-133. [CrossRef]

51. Swertfeger, D.K.; Rebholz, S.; Li, H.; Shah, A.S.; Davidson, W.S.; Lu, L.J. Feasibility of a plasma bioassay to assess oxidative protection of low-density lipoproteins by high-density lipoproteins. J. Clin. Lipidol. 2018, 12, 1539-1548. [CrossRef]

52. Hine, D.; Mackness, B.; Mackness, M. Coincubation of PON1, APO A1, and LCAT increases the time HDL is able to prevent LDL oxidation. IUBMB Life 2011, 64, 157-161. [CrossRef] [PubMed]

53. Silva, P.R.; Jannes, C.E.; Marsiglia, J.D.; Krieger, J.E.; Santos, R.D.; Pereira, A.C. Predictors of cardiovascular events after one year of molecular screening for Familial hypercholesterolemia. Atherosclerosis 2016, 250, 144-150. [CrossRef] [PubMed]

54. van den Berg, E.H.; Gruppen, E.G.; James, R.W.; Bakker, S.J.L.; Dullaart, R.P.F. Serum paraoxonase 1 activity is paradoxically maintained in nonalcoholic fatty liver disease despite low HDL cholesterol. J. Lipid Res. 2019, 60, 168-175. [CrossRef]

55. van Himbergen, T.M.; Roest, M.; de Graaf, J.; Jansen, E.H.J.M.; Hattori, H.; Kastelein, J.J.P.; Voorbij, H.A.; Stalenhoef, A.F.; van Tits, L.J. Indications that paraoxonase-1 contributes to plasma high density lipoprotein levels in familial hypercholesterolemia. J. Lipid Res. 2005, 46, 445-451. [CrossRef] [PubMed]

56. Idrees, M.; Siddiq, A.R.; Ajmal, M.; Akram, M.; Khalid, R.R.; Hussain, A.; Qamar, R.; Bokhari, H. Decreased serum PON1 arylesterase activity in familial hypercholesterolemia patients with a mutated LDLR gene. Genet. Mol. Biol. 2018, 41, 570-577. [CrossRef] [PubMed]

57. Desgagné, V.; Bouchard, L.; Guerin, R. MicroRNAs in lipoprotein and lipid metabolism: From biological function to clinical ap-plication. Clin. Chem. Lab. Med. 2017, 55, 667-686. [CrossRef] [PubMed]

58. Desgagné, V.; Guérin, R.; Guay, S.P.; Boyer, M.; Hutchins, E.; Picard, S.; Maréchal, A.; Corbin, F.; Van Keuren-Jensen, K.; Arsenault, B.J.; et al. Human high-density lipoprotein microtranscriptome is unique and suggests an extended role in lipid metabolism. Epigenomics 2019, 11, 917-934. [CrossRef]

59. Vickers, K.C.; Palmisano, B.T.; Shoucri, B.M.; Shamburek, R.D.; Remaley, A.T. MicroRNAs are transported in plasma and delivered to recipient cells by high-density lipoproteins. Nat. Cell Biol. 2011, 13, 423-433. [CrossRef] [PubMed]

60. D’Agostino, M.; Martino, F.; Sileno, S.; Barillà, F.; Beji, S.; Marchetti, L.; Gangi, F.M.; Persico, L.; Picozza, M.; Montali, A.; et al. Circulating miR-200c is up-regulated in paediatric patients with familial hypercholesterolaemia and correlates with miR-33a/b levels: Implication of a ZEB1-dependent mechanism. Clin. Sci. (Lond) 2017, 131, 2397-2408. [CrossRef]

61. Scicali, R.; Di Pino, A.; Pavanello, C.; Ossoli, A.; Strazzella, A.; Alberti, A.; Di Mauro, S.; Scamporrino, A.; Urbano, F.; Filippello, A.; et al. Analysis of HDL-microRNA panel in heterozygous familial hypercholesterolemia subjects with LDL receptor null or defective mutation. Sci. Rep. 2019, 9, 20354. [CrossRef] [PubMed]

62. Prats-Uribe, A.; Sayols-Baixeras, S.; Fernández-Sanlés, A.; Subirana, I.; Carreras-Torres, R.; Vilahur, G.; Civeira, F.; Marrugat, J.; Fitó, M.; Hernáez, Á.; et al. High-density lipoprotein characteristics and coronary artery disease: A Mendelian randomization study. Metabolism 2020, 112, 154351. [CrossRef] [PubMed]

63. van Aalst-Cohen, E.S.; Jansen, A.C.M.; Boekholdt, S.M.; Tanck, M.W.T.; Fontecha, M.R.; Cheng, S.; Li, J.; Defesche, J.C.; Kuivenhoven, J.A.; Kastelein, J.J. Genetic determinants of plasma HDL-cholesterol levels in familial hypercholesterolemia. Eur. J. Hum. Genet. 2005, 13, 1137-1142. [CrossRef] [PubMed]

64. Eichler, E.E.; Flint, J.; Gibson, G.; Kong, A.; Leal, S.M.; Moore, J.H.; Nadeau, J.H. Missing heritability and strategies for finding the underlying causes of complex disease. Nat. Rev. Genet. 2010, 11, 446-450. [CrossRef] [PubMed]

65. Hegele, R.A. Environmental modulation of atherosclerosis end points in familial hypercholesterolemia. Atheroscler. Suppl. 2002, 2, 5-7. [CrossRef]

66. van der Graaf, A.; Vissers, M.N.; Gaudet, D.; Brisson, D.; Sivapalaratnam, S.; Roseboom, T.J.; Jansen, A.C.; Kastelein, J.J.; Hutten, B.A. Dyslipidemia of mothers with familial hypercholesterolemia deteriorates lipids in adult offspring. Arter. Thromb. Vasc. Biol. 2010, 30, 2673-2677. [CrossRef] [PubMed] 
67. Langmann, T.; Porsch-Ozcürümez, M.; Heimerl, S.; Probst, M.; Moehle, C.; Taher, M.; Borsukova, H.; Kielar, D.; Kaminski, W.E.; Dittrich-Wengenroth, E.; et al. Identification of sterol-independent regulatory elements in the human ATP-binding cassette transporter A1 promoter: Role of Sp1/3, E-box binding factors and an oncostatin M-responsive element. J. Biol. Chem. 2002, 277, 14443-14450. [CrossRef] [PubMed]

68. Guay, S.P.; Brisson, D.; Munger, J.; Lamarche, B.; Gaudet, D.; Bouchard, L. ABCA1gene promoter DNA methylation is associated with HDL particle profile and coronary artery disease in familial hypercholesterolemia. Epigenetics 2012, 7, 464-472. [CrossRef]

69. Guay, S.; Brisson, D.; Lamarche, B.; Marceau, P.; Vohl, M.; Gaudet, D.; Bouchard, L. DNA methylation variations at CETP and LPL gene promoter loci: New molecular biomarkers associated with blood lipid profile variability. Atherosclerosis 2013, 228, 413-420. [CrossRef]

70. Guay, S.P.; Voisin, G.; Brisson, D.; Munger, J.; Lamarche, B.; Gaudet, D.; Bouchard, L. Epigenome-wide analysis in familial hypercholesterolemia identified new loci associated with high-density lipoprotein cholesterol concentration. Epigenomics 2012, 4, 623-639. [CrossRef]

71. Guay, S.P.; Légaré, C.; Brisson, D.; Mathieu, P.; Bossé, Y.; Gaudet, D.; Bouchard, L. Epigenetic and genetic variations at the TNNT1 gene locus are associated with HDL-C levels and coronary artery disease. Epigenomics 2016, 8, 359-371. [CrossRef]

72. Guay, S.P.; Brisson, D.; Lamarche, B.; Gaudet, D.; Bouchard, L. Epipolymorphisms within lipoprotein genes contribute independently to plasma lipid levels in familial hypercholesterolemia. Epigenetics 2014, 9, 718-729. [CrossRef]

73. Tomás, M.; Sentí, M.; García-Faria, F.; Vila, J.; Torrents, A.; Covas, M.; Marrugat, J. Effect of simvastatin therapy on paraoxonase activity and related lipoproteins in familial hypercholesterolemic patients. Arter. Thromb. Vasc. Biol. 2000, 20, $2113-2119$. [CrossRef] [PubMed]

74. Deakin, S.; Leviev, I.; Guernier, S.; James, R.W. Simvastatin modulates expression of the PON1 gene and increases serum paraoxonase: A role for sterol regulatory element-binding protein-2. Arterioscler. Thromb. Vasc. Biol. 2003, 23, $2083-2089$. [CrossRef] [PubMed]

75. Van Himbergen, T.M.; Tits, L.J.H.; de Voorbij, H.A.M.; Graaf, J.; Stalenhoef, A.F.H.; Roest, M. The effect of statin therapy on plasma high-density lipoprotein cholesterol levels is modified by paraoxonase-1 in patients with familial hypercholesterolaemia. J. Intern. Med. 2005, 258, 442-449. [CrossRef] [PubMed]

76. Kastelein, J.J.; Ginsberg, H.N.; Langslet, G.; Hovingh, G.K.; Ceska, R.; Dufour, R.; Blom, D.; Civeira, F.; Krempf, M.; Lorenzato, C.; et al. ODYSSEY FH I and FH II: 78 week results with alirocumab treatment in 735 patients with heterozygous familial hypercholesterolemia. Eur. Heart J. 2015, 43, 2996-3003. [CrossRef]

77. Raal, F.J.; Stein, E.A.; Dufour, R.; Turner, T.; Civeira, F.; Burgess, L.; Langslet, G.; Scott, R.; Olsson, A.G.; Sullivan, D.; et al. PCSK9 inhibition with evolocumab (AMG 145) in heterozygous familial hypercholesterolemia: (RUTHERFORD-2): A randomised, double-blind, placebo-controlled trial. Lancet 2015, 385, 331-340. [CrossRef]

78. Sabatine, M.S.; Giugliano, R.P.; Keech, A.C.; Honarpour, N.; Wiviott, S.D.; Murphy, S.A.; Kuder, J.F.; Wang, H.; Liu, T.; Wasserman, S.M.; et al. Evolocumab and clinical outcomes in patients with cardiovascular disease. N. Engl. J. Med. 2017, 376, 1713-1722 [CrossRef] [PubMed]

79. Schwartz, G.G.; Steg, P.G.; Szarek, M.; Bhatt, D.L.; Bittner, V.A.; Diaz, R.; Edelberg, J.M.; Goodman, S.G.; Hanotin, C.; Harrington, R.A.; et al. Alirocumab and cardiovascular outcomes after acute coronary syndrome. N. Engl. J. Med. 2018, 379, 2097-2107. [CrossRef]

80. Burnap, S.A.; Joshi, A.; Tsimikas, S.; Fernández-Hernando, C.; Kiechl, S.; Berry, S.E.; Hall, W.; Levkau, B.; Mayr, M. High-density lipoproteins are the main carriers of PCSK9 in the circulation. J. Am. Coll. Cardiol. 2020, 75, 1495-1497. [CrossRef]

81. Aung, L.H.; Yin, R.X.; Miao, L.; Hu, X.J.; Yan, T.T.; Cao, X.L.; Wu, D.F.; Li, Q.; Pan, S.L.; Wu, J.Z. The proprotein convertase subtilisin/kexin type 9 gene E670G polymorphism and serum lipid levels in the Guangxi Bai Ku Yao and Han populations. Lipids Health Dis. 2011, 10, 5. [CrossRef]

82. Lakoski, S.G.; Lagace, T.A.; Cohen, J.C.; Horton, J.D.; Hobbs, H.H. Genetic and metabolic determinants of plasma PCSK9 levels. J. Clin. Endocrinol. Metab. 2009, 94, 2537-2543. [CrossRef] [PubMed]

83. Baass, A.; Dubuc, G.; Tremblay, M.; Delvin, E.E.; O'Loughlin, J.; Levy, E.; Davignon, J.; Lambert, M. Plasma PCSK9 is associated with age, sex, and multiple metabolic markers in a population-based sample of children and adolescents. Clin. Chem. 2009, 55, 1637-1645. [CrossRef] [PubMed]

84. Ferri, N.; Corsini, A.; Macchi, C.; Magni, P.; Ruscica, M. Proprotein convertase subtilisin kexin type 9 and high-density lipoprotein metabolism: Experimental animal models and clinical evidence. Transl. Res. 2016, 173, 19-29. [CrossRef] [PubMed]

85. Li, B.; Hao, P.P.; Zhang, Y.; Yin, R.-H.; Kong, Q.-Z.; Cai, X.-J.; Zhao, Z.; Qi, J.-N.; Li, Y.; Xiao, J.; et al. Efficacy and safety of proprotein convertase subtilisin/kexin type 9 monoclonal antibody in adults with familial hypercholesterolemia. Oncotarget 2016, 8, 30455-30463. [CrossRef] [PubMed]

86. Qian, L.J.; Gao, Y.; Zhang, Y.M.; Chu, M.; Yao, J.; Xu, D. Therapeutic efficacy and safety of PCSK9-monoclonal antibodies on familial hypercholesterolemia and statin-intolerant patients: A meta-analysis of 15 randomized controlled trials. Sci. Rep. 2017, 7, 238. [CrossRef] [PubMed]

87. Rodriguez, A.; Trigatti, B.L.; Mineo, C.; Knaack, D.; Wilkins, J.T.; Sahoo, D.; Asztalos, B.F.; Mora, S.; Cuchel, M.; Pownall, H.J.; et al. Proceedings of the ninth HDL (high-density lipoprotein) workshop: Focus on cardiovascular disease. Arter. Thromb. Vasc. Biol. 2019, 39, 2457-2467. [CrossRef] [PubMed] 